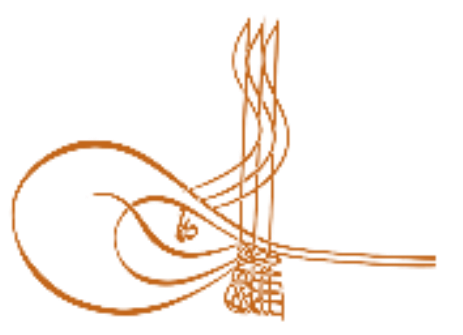

www.turkishstudies.net/turkishstudies
Turkish Studies

eISSN: $1308-2140$

Research Article / Araştırma Makalesi

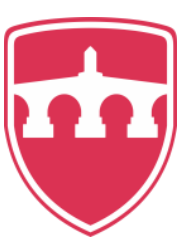

INTERNATIONAL

BALKAN

UNIVERSITY

Sponsored by IBU

\title{
İhracat Kredi Sigortalarının İhracata Etkisi Üzerine Bir Araştırma
}

A Research on the Effect of Export Credit Insurance on Export

\author{
Ahu Coşkun Özer*
}

\begin{abstract}
Export credit insurance is provided in order to promote export in the world and in our country. Export credit insurance is based on the compensation of the loss by the insurance company in case the exporting company fails to take its receivables. With the export credit insurance system, which has become widespread since the 2000s, it is aim to improve the export by eliminating the risk of non-payment of the buyer. This type of insurance can be implemented with government support all over the world and it is implemented by a few private sector. Although the studies carried out in the world reveal the positive effect of export credit insurance on exports, the studies conducted in export credit insurance in our country have been limited. In this study, the effect of export credit insurance, which is applied to increase the exports in Turkey is analyzed by correlation, regression analysis and Granger causality test, using annual data. For this purpose, the Turkish Eximbank's shipment value of insured exports data between 2003 and 2018, and Turkey's total foreign trade volume, export value, uninsured shipment value, export credit value, consumer confidence index values from Turkish Statistical Institute are used. According to the results of the research, it has been determined that the export of insured shipments has increased over the years in Turkey but the increase is more limited than the increase in uninsured shipments. In addition, a statistically significant and positive relationship has been determined between the insured shipment value in export credit insurance and uninsured shipment, export volume, eximbank loans and foreign trade volume. A statistically significant and negative correlation has been found between insured shipment value and consumer confidence index. Insured shipments in exports decrease with the increase in consumer confidence.
\end{abstract}

Structured Abstract: A number of risks may arise in payment and delivery in foreign trade transactions. These risks vary depending on the economic and political situation of the countries. At this point, different forms of payment have been developed in foreign trade. Documentary payment, payment against goods, letter of credit payment, cash payment methods are used as payment methods. Despite these regulations, it is important to eliminate the risks that may arise in foreign trade in order to improve foreign trade in countries. For this purpose, countries started to spread insurance applications in foreign trade transactions in order to encourage exports.

\footnotetext{
${ }^{*}$ Dr. Öğr. Üyesi, Marmara Üniversitesi, Sosyal Bilimler Meslek Yüksekokulu, Dış Ticaret Programı Asst. Prof. Dr.,Marmara University, Vocational School of Social Sciences, Foreign Trade Program ORCID 0000-0002-5579-291X

ahu.coskun@marmara.edu.tr

Cite as/ Atıf: Coşkun Özer, A. (2020). İhracat Kredi sigortalarının ihracata etkisi üzerine bir araştırma, Turkish Studies, 15(1), 83-92. https://dx.doi.org/10.29228/TurkishStudies.40253

Received/Geliş: 22 December/Aralık 2019

Accepted/Kabul: 25 February/Şubat 2020

Copyright $(\mathrm{C}$ MDE, Turkey
} 
One of these practices, export credit insurance, which is applied to eliminate the risks in foreign trade transactions, has became widespread especially after the 2008 financial crisis. Export credit insurance-related products, which are widely applied in many countries around the world with government support, are also developed by a small number of private sectors.

Export credit insurance is provided in order to promote export in the world and in our country. Export credit insurance is based on the compensation of the loss by the insurance company in case the exporting company fails to take its receivables. With the export credit insurance system, which has become widespread since the 2000s, it is aim to improve the export by eliminating the risk of non-payment of the buyer. The studies are carried out for the effect of export credit insurance. When the research results are evaluated, export credit insurance has a positive effect on the export and foreign trade of many countries. Although the studies carried out in the world reveal the positive effect of export credit insurance on exports, the studies conducted in export credit insurance in our country have been limited. In this study, the effect of export credit insurance on export, which is applied for the purpose of promoting export in our country, is examined and also the factors affecting export credit insurance are tried to be determined.

In Turkey, export credit insurance is provided by Türk Eximbank. This insurance insures short-term or medium and long-term export receivables. When the shipment insured amounts evaluated between the 20032018 years. The worth of the insured export was \$ 3 million in 2003, this figure has increased to 16 million in 2018. After 2010, insured values increased in export with not only in short term but also in medium and long term insurance applications. According to Eximbank data, approximately 5 million dollars of shipments in 2010, 5 million 752 thousand dollars in 2011, 6 million 923 thousand dollars in 2012, 8 million 376 thousand dollars in 2013, 11 million dollars in 2014, 10 million dollars in 2015, 11 million dollars in 2016 In 2017,15 million dollars were insured. When the Turkey's export value evaluated in the same years, it was aproximately 47 billion dollars in 2003 and it reached nearly 168 billion dollars in 2018. Export figures were approximately 113 billion dollars in 2010, 134 billion dollars in 2011, 152 billion dollars in 2012, 151 billion dollars in 2013, 157 billion dollars in 2014, 143 billion dollars in 2015, 142 billion dollars in 2016 and it has been above 156 billion dollars in 2017.

In the scope of the research, shipment value of insured exports between 2018 and 2003 and export credit value obtained from Eximbank and analysed. Turkey's total foreign trade volume, export value, uninsured shipment value and consumer confidence index values obtained from Turkstat(TÜİK) and analyzed on an annual basis. SPSS 17.0 for Windows and Eviews 7.1 software were used for data analysis. First of all, unit root tests of the data were performed, then the trends were analyzed according to years and finally, performed a regression analysis with year-controlled and Granger causality test was performed.

According to the results of the research, it has been determined that the export of insured shipments has increased over the years in our country, but the increase in insured shipments is more limited than the increase in uninsured shipments. In addition to these, according to the analysis results, statistically significant and positive direction between export volume and insured shipment $(\mathrm{r}=0.953 ; \mathrm{p}<0.01)$, uninsured shipment $(\mathrm{r}=0.991 ; \mathrm{p}<0.01)$ and foreign trade volume $(\mathrm{r}=0.959 ; \mathrm{p}<0.01)$. There is a statistically significant and negative relationship with the consumer confidence index $(r=-0.634 ; p<0.05)$. The results briefly analysed, it shows that statistically significant and positive relationship has been determined between the insured shipment value in export credit insurance and uninsured shipment, export volume, eximbank loans and foreign trade volume. A statistically significant and negative correlation has been found between insured shipment value and consumer confidence index. Insured shipments in exports decrease with the increase in consumer confidence.

Keywords: Export credit insurance, foreign trade volume, export credits

Öz: Dünyada ve ülkemizde ihracatı teşvik etmek amacıyla ihracat kredi sigortası yapılmaktadır. İhracat kredi sigortası, ihracat yapan firmaların alacaklarını, alıcı firmanın ödeyememesi durumunda zararın sigorta tarafından tazmin edilmesine dayanmaktadır. Ülkemizde 2000'li yıllardan itibaren yaygınlaşmaya başlayan ihracat kredi sigortası sistemi ile alıcı firmanın ödeyememe riski ortadan kaldırılarak ihracatın geliştirilmesi amaçlanmaktadır. Bu sigorta türü, tüm dünyada devlet desteği ile uygulanabildiği gibi az sayıda özel sektör tarafından da uygulamaları görülmektedir. Dünyada yapılan çalışmalar ihracat kredi sigortasının ihracata olumlu etkisini ortaya çıkarsa da ülkemizde bu alanda yapılan çalışmalar sınırlı kalmıştır. Bu çalışmada

Turkish Studies, 15(1) 
ülkemizde ihracatı teşvik amacıyla uygulanan ihracat kredi sigortasının ihracata etkisi, yıllık veriler kullanılarak korelasyon, regresyon analizi ve Granger nedensellik testi ile incelenmiştir. Bunun için Türk Eximbank'ın 2003 yılları ile 2018 yılları arasındaki ihracatta sigortalanan sevkiyat değerleri, TÜİK'ten alınan Türkiye'nin toplam dış ticaret hacmi, ihracat değerleri, sigortasız sevkiyat değerleri, ihracat kredi değerleri, tüketici güven indeksi değerleri kullanılmıştır. Araştırma sonuçları değerlendirildiğinde ülkemizde ihracatta, sigortalı sevkiyatın yıllar içerisinde artış gösterdiğini, fakat görülen artışın sigortasız sevkiyattaki artışa göre daha sınırlı olduğu belirlenmiştir. Ayrıca korelasyon analizi sonucuna göre ihracat kredi sigortasında, sigortalanan sevkiyat değeriyle sigortasız sevkiyat, ihracat hacmi, eximbank kredileri ve dış ticaret hacmi arasında istatistiksel olarak anlamlı ve pozitif yönde ilişki belirlenmiştir. Sigortalı sevkiyat değeri ile tüketici güven indeksi arasında ise istatistiksel olarak anlamlı ve negatif ilişki bulunmuştur. Tüketici güvenindeki artışla birlikte ihracatta sigortalı sevkiyat azalmaktadır.

Anahtar Kelimeler: İhracat kredi sigortası, dış ticaret hacmi, ihracat kredileri

\section{Giriş}

Dış ticaret işlemlerinde ödemede ve teslimde bir takım riskler ortaya çıkabilmektedir. $\mathrm{Bu}$ riskler ülkelerin ekonomik ve politik durumlarına bağlı olarak değişmektedir. Bu noktada dış ticarette farklı ödeme şekilleri geliştirilmiştir. Ödeme şekilleri olarak vesaik mukabili ödeme, mal mukabili ödeme, akreditifli ödeme, peşin ödeme yöntemleri kullanılmaktadır. Bu yöntemelere rağmen dış ticarette ortaya çıkabilecek riskleri ortadan kaldırmak ve ülkelerde dış ticareti geliştirmek önem taşımaktadır. Bunun için ülkeler ihracatları teşvik etmek amacıyla dış ticaret işlemlerinde sigorta uygulamalarını yaygınlaştırmaya başlamıştır. $\mathrm{Bu}$ uygulamalardan biri olan ve dış ticaret işlemlerindeki riski ortadan kaldırmaya yönelik uygulanan ihracat kredi sigortası özellikle 2008 finansal krizinden sonra tüm dünyada yaygınlaşmaya başlamıştır. Dünyada yaygın olarak birçok ülkede devlet desteği ile uygulanan ihracat kredi sigortası ile ilgili ürünler çok az sayıda özel sektör tarafından da geliştirilmektedir.

Yıllardır uygulanan ihracatı teşvik amacıyla geliştirilen ihracat kredi sigortasının etkisine yönelik çalışmalarda yapılmaktadır. Araştırma sonuçları değerlendirildiğinde ihracat kredi sigortası birçok ülkenin ihracatına ve dış ticaretine pozitif yönde etki etmektedir. Ancak ülkemizde uygulanan ihracat kredi sigortasının ihracata etkisi konusunda yapılan çalışmalar sınırlı kalmıştır. Ülkemizde Türk Eximbank tarafindan ihracat kredi sigortası yapılmaktadır. Bu sigorta kısa vadeli veya orta ve uzun vadeli ihracattan doğan alacakları sigortalamaktadır. Bu çalışmada, ülkemizde ihracatı teşvik amacıyla uygulanan ihracat kredi sigortasının ihracata etkisi belirlenmeye çalışılmıştır. Bunun için Türk Eximbank'ın sigortalanan ihracat değerleri, TÜIK'in toplam Türkiye'nin toplam diş ticaret hacmi, ihracat değerleri, sigortasız sevkiyat değerleri, ihracat kredi değerleri, tüketici güven indeksi değerleri veri olarak kullanılmıştır.

Araştırma sonuçları, ülkemizde sigortalanan ihracat değerinin, ülkenin toplam ihracat değerine etkisini açıklayabildiğini gösternektedir. Araştırma sonuçları değerlendirildiğinde, ülkemizde ihracatta sigortalı sevkiyatın yıllar içerisinde artış gösterdiğini, fakat görülen artışın sigortasız sevkiyattaki artışa göre daha sınırlı olduğu belirlenmiştir. Ayrıca ihracat kredi sigortasında sigortalanan sevkiyat değeriyle sigortasız sevkiyat, ihracat hacmi, eximbank kredileri ve dış ticaret hacmi arasında istatistiksel olarak anlamlı ve pozitif yönde ilişki belirlenmiştir.

\section{Türkiye'de İhracat Kredi Sigortası Ve Türkiye'nin İhracatı}

Türkiye'de ihracat kredi sigortası Türk Eximbank tarafından 2003 yılından 2010 yılına kadar kısa vadeli ihracat alacaklarına yapılmaktaydı. Bu uygulama kapsamında 2010 yılı itibariyle yalnızca kısa vadeli ihracatın değil orta ve uzun vadeli ihracattan doğan alacakların da sigortalanmasına başlanmıştır. Günümüzde de yalnızca kısa vadeli ihracat kredi sigortası değil orta ve uzun vadeli ihracat kredi sigortası yapilmaktadır. Orta ve uzun vadeli ihracat kredi sigortasında 18 y1l kadar vadeli sevkiyatlardan doğacak olan alacaklar teminat altına alınmaktadır. Ancak orta ve uzun vadeli 
sigortalanan ihracat kredi değerleri kısa vadeli ihracat kredi değerlerine göre oldukça düşük miktardadır.

Türk Eximbank verilerine göre, 2018 y1lı sonu itibarıyla 151 firma ihracat kredi sigortası hizmeti almıştır. Türk Eximbank 10 bin 418 alıcı, 2.198 milyon ABD doları tutarındaki sevkiyatını limitler dahilinde kısa vadeli ihracat kredi sigortası ile sigortalamıştır. Sigortalanan sevkiyatlar için 136,6 bin dolar değerinde tazminat ödenmiştir. 2018 yılında Eximbank tarafindan 160,2 milyon dolar değerinde sevk sonrası ve sevk öncesi risk poliçeleri kapsamında ihracat kredi sigorta desteği sağlanmıştır ve 682 bin 497 dolar değerinde sevk sonrası poliçeler için tazminat ödemesi yapılmıştır(Türk Eximbank,2018:32).

Grafik 1:Türkiye'de 2003-2018 Yılları Arasında Türk Eximbank’1n Sigortaladığı Sevkiyat Değeri (Bin Dolar)

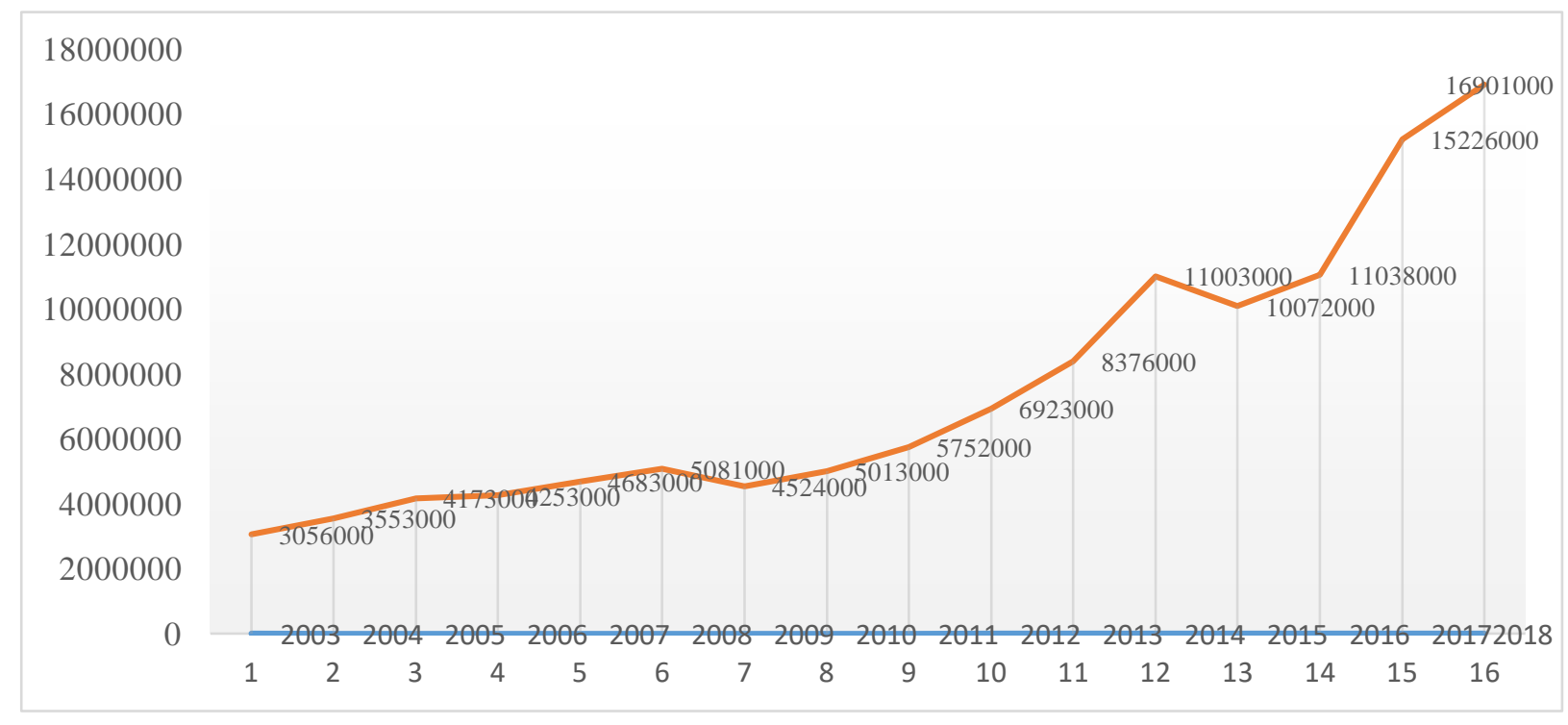

Kaynak: Türk Eximbank Faaliyet Raporları,2003-2018

Türkiye'de 2003 yılında 2018 yılına kadar sigortalanan sevkiyat tutarları incelendiğinde, 2003 yılında 3 milyon dolar değerinde sevkiyat sigortalanırken, bu rakam 2018 yılında 16 milyon 900 bin dolara çıkmıştır. 2010 yılı sonrasında yalnızca kısa vadeli değil orta ve uzun vadeli sevkiyatlarında sigortalanması ile birlikte sigortalanan değerler artış göstermeye başlamıştır. Eximbank verilerine göre 2010 yılında yaklaşı 5 milyon dolar sevkiyat, 2011 yılında 5 milyon 752 bin dolar, 2012 yılında 6 milyon 923 bin dolar, 2013 y1lında 8 milyon 376 bin dolar, 2014 yılında 11 milyon dolar, 2015 yılında 10 milyon dolar, 2016 yilında 11 milyon dolar, 2017 y1lında 15 milyon dolar değerinde sigortalanan sevkiyat bulunmaktadır. 
Grafik 2: Türkiye’nin İhracat Değeri 2003-2018 (Bin Dolar)

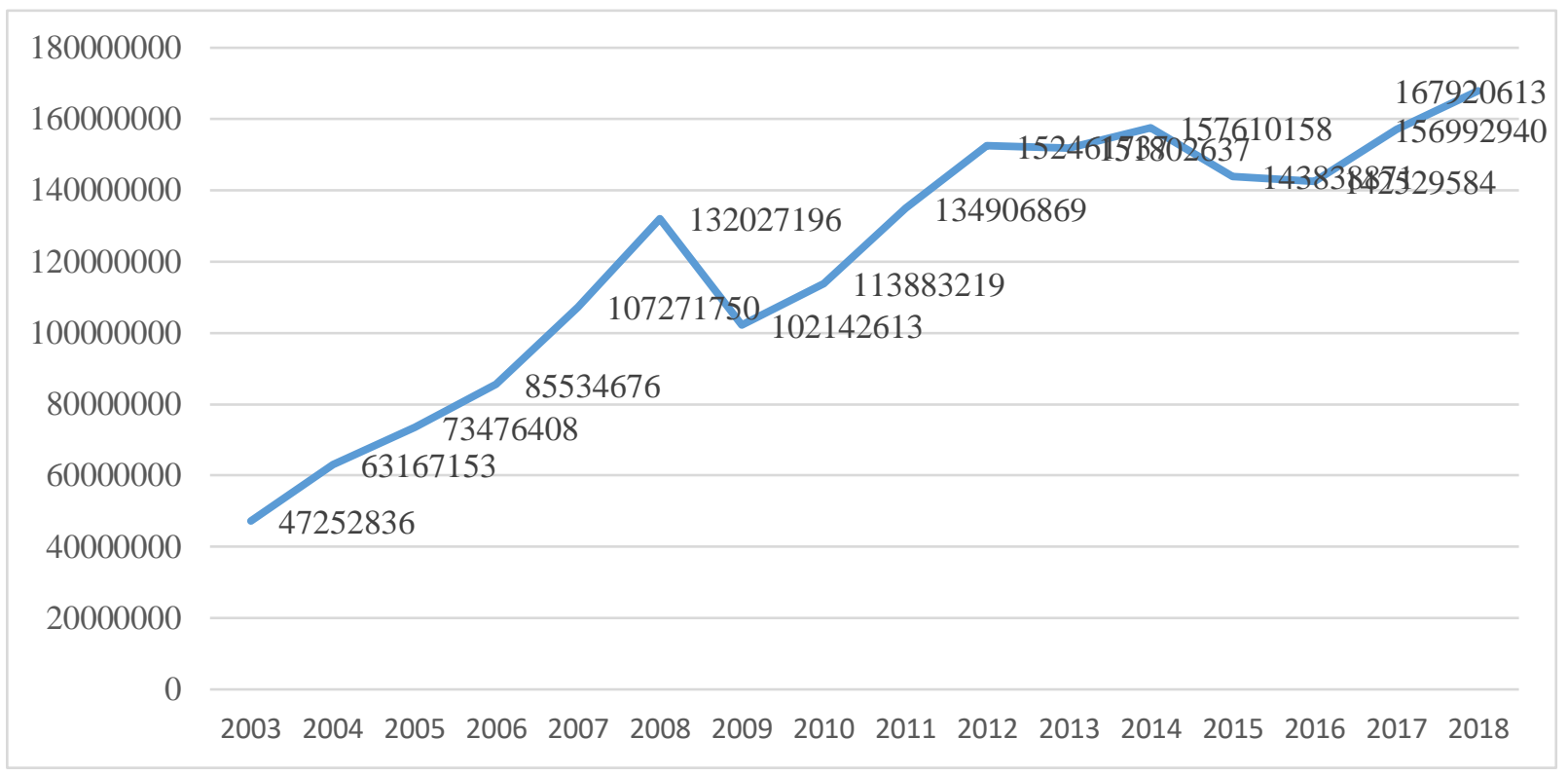

Kaynak: TÜIK,2003-2018

Aynı yıllar içerisinde Türkiye'nin ihracatı incelendiğinde Grafik 2'den de görüldüğü gibi, 2003 yılında yaklaşık 47 milyar dolarken 2018 yılında 168 milyar dolara yaklaşmıştır. İhracat rakamları 2010 y1lında yaklaşı 113 milyar dolar, 2011'de 134 milyar dolar, 2012'de 152 milyar dolar, 2013 y1lında 151 milyar dolar, 2014 y1lında 157 milyar dolar, 2015'te 143 milyar dolar, 2016'da 142 milyar dolar, 2017'de ise 156 milyar doların üzerinde seyretmiştir.

\section{Literatür Taraması}

İhracat kredi sigortası dünyadaki uygulamalarına bakıldığında, Avrupa'da özellikle 2008 finansal krizi sonrasında bu sitemin uygulanması için özel sigorta şirketlerine yardım yapılmıştır. 2008 yılında yaşanan finansal krizinin bir sonucu olarak Avrupa Komisyonu, AB üyesi devletlerdeki iki yıldan az süreli ödemeli ihracat işlemlerini garanti altına almak için uzman kuruluşlara ödenek vermiştir ve bu izin Aralık 2011 yılına kadar geçerli olmuştur(Rosu, Gavrila \& diğerleri, 2011:968). Günümüzde ise kısa vadeli ihracat işlemlerinde geri ödeme riskini kapsayan ihracat kredi sigortası AB içinde genel olarak özel sigorta şirketleri tarafindan sağlanmaktadır (Morel, 2011, as cited in Veer, 2019:74).

Rosu, Gavrila ve diğerleri (2011), 'İhracat Kredi Sigortası, Devlet Yardımının Bir Diğer Şekli mi?' başlılıklı çalışmasında, ülke ekonomilerini rekabete karşı korumak amacıyla uygulanan ihracat kredi sigortalarının devlet tarafından yapıldığından, devlet desteği ve sübvansiyon olup olmadığına dair soruların olduğunu belirtmektedir. Gavrila (2008) ise 'Sözleşmeli İhracat' başlıklı çalışmasında, ihracat kredi sigortasının her ne olursa olsun alıcının konumunu güçlendirdiğini belirtmektedir. Her ne kadar devlet desteği de olsa yapılan araştırmalar ihracat kredi sigortalarının ihracata olumlu etkisi olduğunu göstermektedir.

Veer tarafından (2015) yapılan 'Özel İhracat Kredi Sigortasının Ticaret Üzerindeki Etkisi’ başlıklı araştırma sonuçlarına göre ihracat kredi sigortalarının ihracata olumlu etkisi olmaktadır. Veer, analiz sonuçlarına göre sigortalı ihracat arzındaki değişimin ticarete etkisi sigortalanmış ihracat değerinden daha büyük olduğunu belirtmiştir ve uluslararası ticarette kredi kullanımına uyarıcı etki yapan özel ihracat kredi sigortalarının rolüne ve önemine dikkat çekmektedir. Wilkinson, Keillor ve d'Amico ise yaptıkları 'ABD'de İhracat Teşvik Harcamaları ile Devlet İhracatı Arasındaki İlişki' 
başlıklı çalışmada (as cited in Köksal, Genç, 2018:158), Amerika'da ihracatı teşvik harcamalarının ihracat ile güçlü bir ilişkisi olduğunu belirtmektedir. Egger ve Url ise (as cited in Köksal, Genç, 2018:158) 'Devlet İhracat Kredi Garantileri ve Dış Ticaret Yapısı' başlıklı çalışmalarında, Avusturya'da ihracat kredi sigortalarının ihracatı pozitif yönde etkilediğini belirtmektedir. Köksal ve Genç (2018) 'İhracat Kredi Sigortalarının İhracat Değeri Üzerindeki Etkisi: Gelişmiş Ülkeler Üzerine bir Panel Veri Analizi' çalışmasında, yüksek gelirli ülkelerin kısa vadeli ihracat kredi sigortalarında yüzde 1'lik artışın, ihracat değerinde ortalama $\% 0,14$ oranında artış sağladığını belirlemiştir.

Ayrıca Berg ve diğerleri (2019) 'Hollanda'da Devlet İhracat Kredi Sigortası Desteği başlıklı çalışmasında ihracat kredi sigortası ile sigortalanan ihracatın GSYIH'ya katkısının yıllık ortalama\% 0.24 olduğunu belirlemiştir. Ayrıca Abgarya ve diğerleri (2017) 'İhracatın Desteklenmesi: Ermenistan'da Kredi Sigortasındaki Zorluklar ve Fırsatlar' başlıklı çalışmasında ihracatın artışı ve sürüdürülebilir büyümenin sağlanması için ihracat kredi sigortasının önemine değinmekte ve bu alanda uluslararası özel kredi sigorta sağlayıcılarının piyasaya girmesi ile politik ve ticari risklerin üstlenilebileceğini ve bu sayede ihracat kredi ajanslarının üzerindeki maliyetlerin azalabileceğini belirtmektedir.

Auboin ve Engemann (2014) 'Ticaret Kredisi ve Ticaret Bağlantısı Testi: İhracat Kredi Sigortası Verilerinden Bulgular' başlıklı çalışmalarında Berne Union verilerini kullanarak 20052011 yılları arasındaki verilerden bir analiz gerçekleştirmişlerdir. Çalışmanın sonuçlarına göre, sigortalanmış açık hesap ticaret, global ticaret hacmi üzerinde oldukça yüksek bir etkiye sahiptir (as cited in Çetiner ve diğerleri, 2018:783).

\section{Methodoloji}

İhracat Kredi Sigortalarının İhracata Etkisi Üzerine Bir Araştırma başlıklı bu çalışma kapsamında, Türk Eximbank tarafindan 2003 yılları ile 2018 yılları arasındaki son onaltı yılda ihracatta sigortalanan sevkiyat değerleri, ihracat kredi değerleri ve TÜİ'ten alınan Türkiye'nin toplam dış ticaret hacmi, ihracat değerleri, sigortasız sevkiyat değerleri ve tüketici güven indeksi değerleri yıllık olarak analiz edilmiştir. Verilerin analizinde SPSS 17.0 for Windows ve Eviews 7.1 paket programları kullanılmıştır. Öncelikle verilerin birim kök testleri yapılmış, ardından yıllara göre trendlerine bakılmış ve son olarak yıl kontrollü regresyon analizi ile Granger nedensellik testi yapılmıştır.

\section{Bulgular}

Araştırmada kullanılan parametrelerin 2003-2018 yılları arasındaki ortalama ve standart sapma değerleri Tablo 1'de yer almaktadır.

Tablo 1: Araştırmada kullanılan parametrelerin 2003-2018 yılları arasındaki ortalama ve standart sapma değerleri

\begin{tabular}{lllll}
\hline & En büyük & En küçük & Ortalama & Std. Sapma \\
\hline Sigortalı sevkiyat & $3.056 .000,00$ & $16.901 .000,00$ & $7.476 .687,50$ & $4.237 .839,90$ \\
Sigortasız sevkiyat & $44.196 .836,00$ & $151.019 .613,00$ & $113.324 .516,25$ & $34.132 .502,48$ \\
İhracat Hacmi & $47.252 .836,00$ & $167.920 .613,00$ & $120.801 .203,75$ & $37.389 .628,93$ \\
Eximbank kredileri & $15.127 .000,00$ & $27.251 .000,00$ & $21.209 .571,43$ & $3.805 .295,25$ \\
Tüketici güven indeksi & 56,70 & 91,90 & 73,09 & 9,91 \\
İhracat birim değeri & 74,60 & 109,80 & 97,00 & 10,37 \\
Diş ticaret hacmi & $116.592 .528,00$ & $403.463 .887,00$ & $305.529 .538,00$ & $93.187 .155,00$ \\
\hline
\end{tabular}

Tablo 1 incelendiğinde, yıllar içerisinde sigortasız sevkiyat ve ihracat hacmi, sigortalı sevkiyata göre daha yüksek değişim aralığına sahiptir. Yıllara göre sigortalı ve sigortasız sevkiyat değerlerinin değişimi Şekil 1'de gösterilmiştir. 

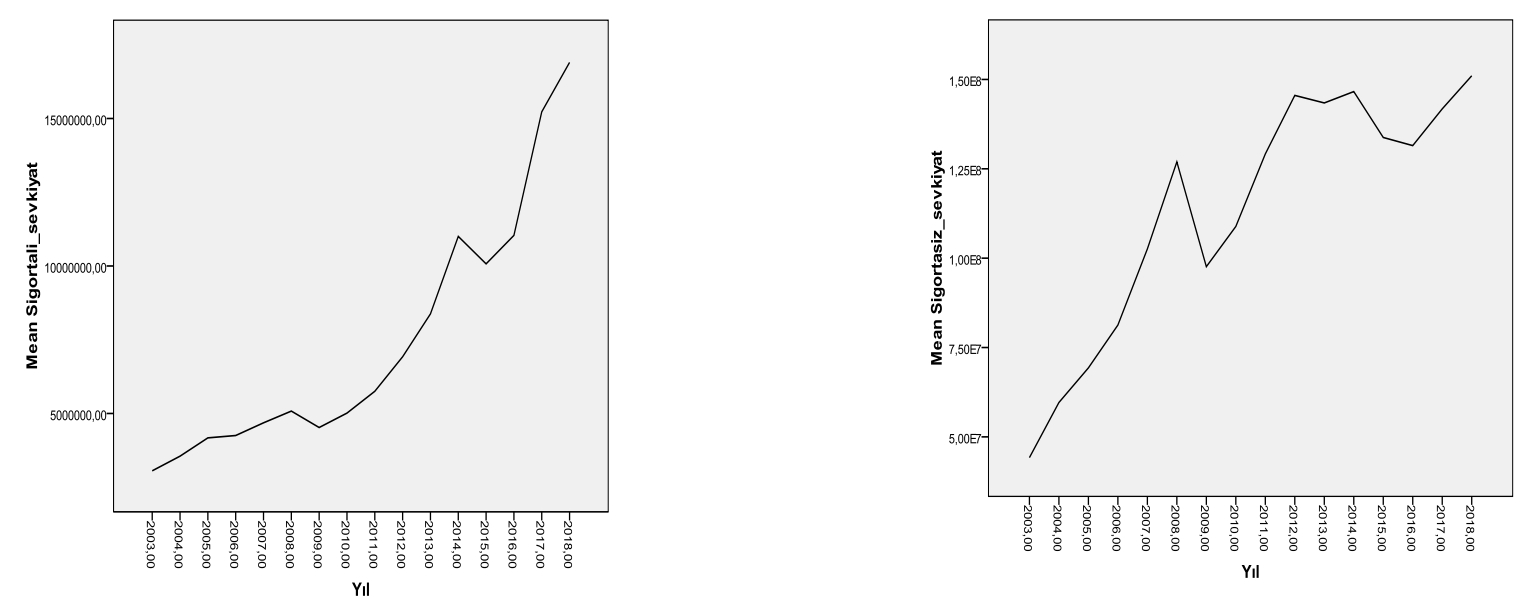

Şekil 1. Y1llara göre sigortalı ve sigortasız sevkiyat değerlerinin değişimi

Şekil 1'de de görüleceği gibi, sigortalı ve sigortasız sevkiyat değerlerinin her ikisinde de artış trendi görülürken, sigortasız sevkiyatın ortalama değeri, sigortalı sevkiyatın ortalama değerinden çok daha yüksektir (Bkz. Tablo 1). Dolayısıyla sigortalı sevkiyatın yıllar içerisinde artış gösterdiğini, fakat görülen artışın sigortasız sevkiyattaki artışa göre daha sınırlı olduğu ifade edilebilir. Araştırma parametrelerinin birim kök testleri için yapılan ADF testi sonuçları Tablo 2'de yer almaktadır.

Tablo 2: Araştırma parametrelerinin birim kök testleri için yapılan ADF testi sonuçları

\begin{tabular}{|c|c|c|c|c|c|c|c|}
\hline & Sabit & $\begin{array}{l}\text { Sabit } \\
\text { Trend }\end{array}$ & $\&$ & $\begin{array}{l}\% 1 \\
\text { Değer }\end{array}$ & Kritik & $\begin{array}{l}\% 5 \quad \text { Kritik } \\
\text { Değer }\end{array}$ & $\begin{array}{l}\text { \%10 Kritik } \\
\text { Değer }\end{array}$ \\
\hline Sigortalı sevkiyat & -800212.3 & -0.930 & & -4.058 & & -3.120 & -2.701 \\
\hline Sigortasız sevkiyat & 29289626.0 & -0.200 & & -3.959 & & -3.081 & -2.681 \\
\hline İhracat Hacmi & 28147936.0 & -0.171 & & -3.959 & & -3.081 & -2.681 \\
\hline Eximbank kredileri & 5449185.0 & -0.170 & & -5.120 & & -3.519 & -2.898 \\
\hline $\begin{array}{l}\text { Tüketici güven } \\
\text { indeksi }\end{array}$ & 37.423 & $-0.537 *$ & & -4.004 & & -3.099 & -2.690 \\
\hline İhracat birim değeri & 42.313 & $-0.423^{*}$ & & -3.959 & & -3.081 & -2.681 \\
\hline Diş ticaret hacmi & 89099753.0 & -0.236 & & -3.959 & & -3.081 & -2.681 \\
\hline
\end{tabular}

$$
* \mathrm{p}<0.05
$$

Tablo 2 incelendiğinde, sigortalı sevkiyat, sigortasız sevkiyat, ihracat hacmi, dış ticaret hacmi ve Eximbank kredileri birim kök içermekte olup, serilerin durağan olmadığı belirlenmiştir $(\mathrm{p}<0.05)$. Bu nedenle regresyon ve nedensellik analizinde, bu parametrelerin logaritmik dönüşümleri yapılmıştır. Öte yandan tüketici güven indeksi ve ihracatın birim değerinin dağılım serisi birim kök içermemekte olup, seri durağandır(p>0.05). Bu nedenle bu parametreler analize doğrudan dahil edilmiştir. Araştırma parametreleri arasında Spearman's rho korelasyon analizi sonuçları Tablo 3’tedir. 
Tablo 3: Araştırma parametreleri arasında Spearman's rho korelasyon analizi sonuçları

\begin{tabular}{|c|c|c|c|c|c|c|}
\hline & $\begin{array}{l}\text { Ln(Sigortalı } \\
\text { sevkiyat) }\end{array}$ & $\begin{array}{l}\text { Ln(Sigortasiz } \\
\text { sevkiyat) }\end{array}$ & $\begin{array}{l}\text { Ln(İhracat } \\
\text { Hacmi) }\end{array}$ & $\begin{array}{l}\text { Ln } \\
\text { (Eximbank } \\
\text { kredileri) }\end{array}$ & $\begin{array}{l}\text { Tüketici } \\
\text { güven } \\
\text { indeksi }\end{array}$ & $\begin{array}{l}\text { İhracat } \\
\text { birim } \\
\text { değeri }\end{array}$ \\
\hline $\begin{array}{l}\text { Ln(Sigortasiz } \\
\text { sevkiyat) }\end{array}$ & $0.926 * *$ & & & & & \\
\hline $\begin{array}{l}\text { Ln(İhracat } \\
\text { Hacmi) }\end{array}$ & $0.953^{* *}$ & $0.991^{\text {** }}$ & & & & \\
\hline $\begin{array}{l}\text { Ln (Eximbank } \\
\text { kredileri) }\end{array}$ & $0.964^{* *}$ & -0.036 & 0.286 & & & \\
\hline $\begin{array}{l}\text { Tüketici güven } \\
\text { indeksi }\end{array}$ & $-0.704^{* *}$ & $-0.607^{*}$ & $-0.634^{*}$ & $-0.847^{*}$ & & \\
\hline $\begin{array}{l}\text { İhracat birim } \\
\text { değeri }\end{array}$ & 0.309 & $0.503^{*}$ & 0.465 & -0.714 & -0.034 & \\
\hline $\begin{array}{l}\text { Ln (Diş ticaret } \\
\text { hacmi) }\end{array}$ & $0.891^{* *}$ & $0.965^{\text {*** }}$ & $0.959^{* * *}$ & -0.179 & $-0.517^{*}$ & $0.559^{*}$ \\
\hline
\end{tabular}

Tablo 3 incelendiğinde, ihracat hacmi ile sigortalı sevkiyat $(\mathrm{r}=0.953 ; \mathrm{p}<0.01)$, sigortasız sevkiyat $(\mathrm{r}=0.991 ; \mathrm{p}<0.01)$ ve diş ticaret hacmi $(\mathrm{r}=0.959 ; \mathrm{p}<0.01)$ arasında istatistiksel olarak anlamlı ve pozitif yönde; tüketici güven indeksi ile ise istatistiksel olarak anlamlı ve negatif yönde ilişki vardır $(\mathrm{r}=-0.634 ; \mathrm{p}<0.05)$. Sigortalı sevkiyat değeriyle ise sigortasız sevkiyat, ihracat hacmi, Türk Eximbank kredileri ve dış ticaret hacmi arasında istatistiksel olarak anlamlı ve pozitif; tüketici güven indeksi ile istatistiksel olarak anlamlı ve negatif ilişki bulunmuştur $(\mathrm{p}<0.01)$.

Araştırmada regresyon analizi kurulurken, her bir değişkenin tek tek analize dahil edildiği basamaklı (stepwise) yöntem kullanılmıştır. Buna göre tüm değişkenlerin dahil edildiği analiz sonucunda iki model aşağıdaki gibi elde edilmiştir.

Tablo 4: İhracat üzerinde etkili parametrelere yönelik çoklu regresyon analizi sonuçları

\begin{tabular}{|c|c|c|c|c|c|}
\hline \multirow[b]{2}{*}{ Model } & \multicolumn{2}{|c|}{ Standart olmayan katsayılar } & \multirow{2}{*}{$\begin{array}{l}\text { Standart katsaylar } \\
\text { Beta }\end{array}$} & \multirow{2}{*}{$\mathbf{t}$} & \multirow{2}{*}{$\mathbf{p}$} \\
\hline & B & Std. Hata & & & \\
\hline 1 (Sabit) & -0.714 & 3.654 & & -0.195 & 0.853 \\
\hline Ln_sigortası__sevkiyat & 1.042 & 0.195 & 0.923 & 5.353 & 0.003 \\
\hline 2 (Sabit) & -0.381 & 0.397 & & -0.961 & 0.391 \\
\hline Ln_sigortası__sevkiyat & 0.964 & 0.021 & 0.853 & 44.905 & 0.000 \\
\hline Ln sigortalı sevkiyat & 0.070 & 0.003 & 0.390 & 20.521 & 0.000 \\
\hline
\end{tabular}

Tablo 4'te görüldüğ̈̈ gibi, ihracat üzerine birinci modelde sadece sigortasız sevkiyat etki ederken, ikinci modelde sigortalı ve sigortasız sevkiyat değerleri bir arada etkilemektedir $(\mathrm{p}<0.05)$. İlk modelde, sigortasız sevkiyatın tek başına etki değeri 0.1.042 regresyon katsayısına sahipken, sigortalı sevkiyatın dahil edildiği modelde, 0.964 'e düşmüştür. Birinci modelin açıklama gücü $\left(\mathrm{R}^{2}\right)$ \%82.2 iken, sigortalı sevkiyat eklendiğinde modelin açıklama gücü \%99.8'e yükselmektedir.

Sigortalı sevkiyat değerine etki eden faktörler için yapılan regresyon analizi sonucunda ise sadece Eximbank kredilerinin anlamlı katkısı olduğu görülmüştür $\left(R^{2}=0.888 ; \beta_{0}=-11.017 ; \beta_{1}=1.615\right.$; $\mathrm{p}<0.05)$. Diğer değişkenlerin modele anlamlı katkısı olmamıştır. Granger nedensellik testi sonuçları hem ihracat verileri için, hem de sigortalı sevkiyat değerleri için istatistiksel olarak anlamlı olmayan sonuçlar vermiştir ( $\mathrm{p}>0.05)$. Araştırma sonuçlarına göre ülkemizde sigortalı sevkiyatı verilen ihracat kredileri pozitif yönde etkilemektedir. 


\section{Sonuç ve Değerlendirme}

İhracat kredi sigortası, ihracat yapan firmaların alacaklarını alıcı firmanın ödeyememesi durumunda zararın sigorta tarafindan tazmin edilmesine dayanmaktadır. Ülkemizde 2000'li yıllardan itibaren yaygınlaşmaya başlayan ihracat kredi sigortası sistemi ile alıcı firmanın ödeyememe riski ortadan kaldırılarak ihracatın geliştirilmesi amaçlanmaktadır.

Yıllardır uygulanan ihracatı teşvik amacıyla geliştirilen ihracat kredi sigortasının etkisine yönelik çalışmalarda yapılmaktadır. Ancak bu çalışmalar sınırlıdır. Araştırma sonuçları değerlendirildiğinde ülkemizde ihracatta sigortalı sevkiyatın yıllar içerisinde artış gösterdiğini, fakat görülen artışın sigortasız sevkiyattaki artışa göre daha sınırlı olduğu görülmektedir. Sigortalı sevkiyat değeriyle sigortasız sevkiyat, ihracat hacmi,Türk Eximbank kredileri ve diş ticaret hacmi arasında istatistiksel olarak anlamlı ve pozitif yönde ilişki vardır. Sigortalı sevkiyat değeri ile tüketici güven indeksi arasında ise istatistiksel olarak anlamlı ve negatif ilişki bulunmuştur. Tüketici güvenindeki artışla birlikte ihracatta sigortalı sevkiyat azalmaktadır.

Sigortalı sevkiyat değerine etki eden faktörler için yapılan regresyon analizi sonucunda ise sadece Türk Eximbank kredilerinin anlamlı katkısı olduğu görülmüştür. İhracat kredilerindeki artışla birlikte sevkiyat değeri de artış göstermektedir.

Ülkemizde ihracat hacmini etkileyen değişkenler olarak sigortalı sevkiyat, sigortasız sevkiyat, diş ticaret hacmi ile ihracat hacmi arasında anlamlı ve pozitif yönde bir ilişki bulunmaktadır. Sigortalı sevkiyat değerine etki eden faktörler için yapılan regresyon analizi sonucunda ise sadece Türk Eximbank kredilerinin anlamlı katkısı olduğu görülmüştür.

Bu çalışmada ihracat kredi sigortasını etkileyen unsurlar ve ihracat kredi sigortasının ihracata etkisi belirlenmiştir. Bu alanda yapılacak yeni çalışmalar kapsamında ihracat kredi sigortasını ve ihracatı etkileyen farklı değişkenler belirlenebilir ve yapılacak yeni analiz çalışmalarıyla, ülkemizde ihracat kredi sigortası uygulamalarının daha da geliştirilmesi sağlanabilir.

\section{Kaynakça}

Abgaryan,V.,Rosenthal,S. (2017). Supporting Exports: Challenges and Opportunities for Credit Insurance in Armenia. Global Policy.Vol. 8. Issue 3. file:///C:/Users/TEOMAN\%20\%C3\%96ZER/Downloads/Abgaryan_et_al-2017Global_Policy.pdf, http://dx.doi.org/10.1111/1758-5899.12477

Auboin, M., Engemann, M. (2014). Testing the trade credit and trade link: evidence from data on export credit insurance. Review of World Economics, 150, 715-743. http://dx.doi.org/ 10.1007/s10290-014-0195-4

Çetiner, M., Eke, S., Gündoğdu, F. K. (2018). Kredili Satışlarda Kredi Riskinin Transferi Kredi Sigortasının Ekonomik Büyümeye Etkisinin Irdelenmesi Türkiye Örneği. Finans Ekonomi ve Sosyal Araştırmalar Dergisi, Cilt 3, Sayı4, 776-792. http://dx.doi.org/10.29106/fesa.488310

Egger,P., Url,T. (2006). Public Export Credit Guarantees and Foreign Trade Structure. The World Economy 29(4), 399-418. http://dx.doi.org/10.1111/j.1467-9701.2006.00790.x

Gavrilă, S., Gavrilă, S., P., (2008). Contractul de asigurare a creditelor pentru export, Editura Hamangiu, ISBN: 978-973-1836- 42-3, Bucureşti

Koen J. M.,Veer, V. (2019). Loss Shocks in Export Credit Insurance Markets: Evidence From a Global Insurance Group, 2017 The Journal of Risk and Insurance. Vol. 86, No. 1, 73-102. http://dx.doi.org/ 10.1111/jori.12197 
Köksal,C., Güneren G. E. (2018). İhracat Kredi Sigortalarının İhracat Değeri Üzerindeki Etkisi: Gelişmiş Ülkeler Üzerine bir Panel Veri Analizi. Maliye ve Finans Yazıları 2019, s.168, https://dergipark.org.tr/tr/download/article-file/708860

Morel, F. (2011). Credit Insurance in Support of International Trade: Observations Throughout the Crisis, in: J. Chauffour and M. Malouche, eds., Trade Finance During the Great Trade Collapse (Washington DC: The World Bank), pp. 337-355. http://dx.doi.org/10.1596/978-08213-8748-1

Berg,M., Beveren,V.,Lemmers,O., Span,T., Walker, A. N. (2019). Public Export Credit Insurance In The Netherlands: An Input-Output Approach. The World Economy,Wiley. https://onlinelibrary.wiley.com/doi/epdf/10.1111/twec.12824,pp:2776-2789. http://dx.doi.org/10.1111/twec.12824

Rosu, A., Gavrila, S., Cristea, S. Lucia. (2011). Export Credit Insurance, Another Form Of State Aid?, Annals of Daaam for 2011 \& Proceedings of the 22nd International DAAAM Symposium, Volume 22, No. 1, ISSN 1726-9679 ISBN 978-3-901509-83-4, Editor B. Katalinic, Published by DAAAM International, Vienna, Austria, EU, 2011

Türk Eximbank. (2018). 2018 Yılı Faaliyet Raporu. https://www.eximbank.gov.tr/content/files/c1180b82-9cdc-466d-acca1f102991 ecd6/eximbank-faaliyetraporu-2018

Veer,V., K. J. M. (2015). The Private Export Credit Insurance Effect on Trade, Journal of Risk and Insurance, 82(3): 601-624. http://dx.doi.org/10.1111/jori.12034

Wilkinson,T.J., Keillor, B.D., d'Amico, M. (2005). The Relationship Between Export Promotion Spending and State Exports in the US, Journal of Global Marketing, 95-114. http://dx.doi.org/ 10.1300/J042v18n03_05 